Published by LPMP Imperium

Journal homepage: https:/ / ejournal.imperiuminstitute.org/ index.php/JMSAB

\section{Pengaruh bauran promosi dan gaya hidup terhadap minat beli pada kedai kopi serasi}

JMSAB

137

\author{
Yosie Anne Putri \\ Manajemen, Fakultas Bisnis Institute Teknologi dan Bisnis Kalbis, \\ Jakarta, Indonesia
}

\begin{abstract}
The purpose of this research is to understand the influence of promotion mix and lifestyle towards purchase intention of Kedai Kopi Serasi product. This research is a quantitative research with 130 respondent of sample which are consumers of Kedai Kopi Serasi in Cilincing who coincidentally met with the researcher if deemed concerned was appropriate to be used as a source of data by using non-probability sampling method and incedential sampling techniques. The result of this research show that promotion mix influence significantly to purchase intention and lifestyle influence significantly to purchase intention. The implications of this research can be a reference for the management team in formulating Kedai Kopi Serasi increase purchase intention strategy through promotion mix and lifestyle.
\end{abstract}

\begin{abstract}
Abstrak
Penelitian ini bertujuan untuk mengetahui seberapa besar pengaruh bauran promosi dan gaya hidup terhadap minat beli pada Kedai Kopi Serasi. Penelitian ini merupakan penelitian kuantitatif dengan menggunakan jumlah sampel sebanyak 130 responden yang merupakan konsumen Kedai Kopi Serasi di Cilincing yang secara kebetulan bertemu dengan peneliti bila dipandang yang bersangkutan layak digunakan sebagai sumber data, dengan teknik non-probability sampling dan sampling insidential. Dari hasil analisis hipotesis menyatakan bahwa bauran promosi berpengaruh signifikan terhadap minat beli dan gaya hidup berpengaruh signifikan terhadap minat beli. Implikasi dari penelitian ini dapat menjadi acuan bagi tim manajemen dalam merumuskan strategi untuk meningkatkan minat pembelian produk Kedai Kopi Serasi melalui variabel bauran promosi dan gaya hidup.
\end{abstract}

*Email korespondensi: yosieputri15@gmail.com

Pedoman Sitasi: Putri, Y.A. (2019). Pengaruh bauran promosi dan gaya hidup terhadap minat beli pada kedai kopi serasi. Jurnal Manajemen Strategi dan Aplikasi Bisnis, 2(2), 137 - 144.
Paper type

Research paper

Keywords: promotion mix, lifestyle, purchase intention

Received: 12 Jun 2019

Revised: 12 Aug 2019

Accepted: 19 Aug 2019

Online: 31 Aug 2019

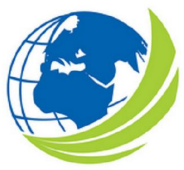

Jurnal Manajemen Strategi dan Aplikasi Bisnis, Vol 1, No. 2 , Desember 2018, pp. 137 - 144 eISSN 2655-237X 


\section{PENDAHULUAN}

Memahami proses pengambilan keputusan konsumen membutuhkan pengetahuan di berbagai bidang seperti, pemasaran, psikologi, ekonomi dan manajemen. Beberapa studi tentang perilaku konsumen telah berusaha untuk memahami logika konsumsi konsumen (Hoppe et al., 2012; dalam Silva, Canavari, \& Wander, 2017). Sebagian besar studi di bidang ini menunjukkan bahwa perhatian pada pola konsumsi makanan tidak hanya terkait dengan kualitas dan harga makanan, namun juga berbagai faktor lain seperti karakteristik biografis dan gaya hidup (Kassim \& Zain, 2016; Asshidin, Abidin \& Borhan, 2016; Kapuge, 2016). Penelitian lainnya menyelidiki permintaan konsumen, umumnya diukur dalam hal kesediaan membayar (willingness-to-pay/WTP) untuk produk dengan tingkat kualitas dan keamanan yang lebih tinggi, di negara-negara seperti Australia, Kanada, Prancis, Jerman, Yunani, Italia, Inggris, Inggris, AS dan lain-lain. Studi lain melibatkan beragam masalah keamanan dan kualitas pangan seperti risiko pangan yang dirasakan oleh konsumen, kualitas produk dan masalah etika dan / atau lingkungan (Silva et al., 2016).

Pesatnya kemajuan teknologi dan informasi telah mengubah perilaku belanja konsumsi masyarakat. Dari sebelumnya pengeluaran konsumsi rumah tangga untuk memenuhi kebutuhan hidup dasar, kini telah bergeser untuk kebutuhan sekunder maupun primer. Hal ini tercermin pengeluaran untuk gaya hidup yang tumbuh di atas konsumsi makanan dan minuman. Berkumpul di kafe - kafe dan coffee shop serta traveling kini telah menjadi gaya hidup bagi masyarakat, terutama para milenial seiring maraknya informasi di media sosial. Berdasarkan data Badan Pusat Statistik Produk Domestik Bruto (PDB) pengeluaran konsumsi rumah tangga untuk restoran dan hotel pada triwulan III 2018 atas dasar harga konstan tumbuh 5,69\% dibanding triwulan III tahun sebelumnya. Meskipun demikian konsumsi makanan minuman masih mendominasi sekitar 39\% pengeluaran rumah tangga. Data tersebut menunjukan bahwa industri makanan dan minuman selalu mengalami perkembangan yang dinamis setiap waktunya. Industri makanan dan minuman tidak hanya digunakan untuk memenuhi kebutuhan pokok konsumen akan tetapi sudah menjadi gaya hidup bagi sebagian besar konsumen. Salah satu bentuk bisnis yang ada pada industri makanan dan minuman adalah kedai kopi.

Indonesia merupakan salah satu negara dengan konsumsi kopi terbesar di dunia. Data International Coffee Organization (ICO) mencatat konsumsi kopi Indonesia periode 2016/2017 mencapai 4,6 juta kemasan $60 \mathrm{~kg} / \mathrm{lb}$ (60 kg) berada di urutan ke-6 negara dengan konsumsi kopi terbesar di dunia di bawah Rusia. Data International Coffee Organization (ICO) menunjukkan bahwa konsumsi kopi Indonesia pada periode 2000 - 2016 mengalami tren kenaikan. Pada 2000, konsumsi kopi Indonesia baru mencapai 1,68 juta bags (bungkus) @60 kg, namun pada 2016 telah mencapai 4,6 juta bags @60 kg, atau naik lebih dari 174\%.Bahkan sejak 2011, konsumsi kopi selalu mengalami pertumbuhan hingga 2016. Indonesia merupakan salah satu negara terbesar penghasil dan pengekspor komoditas kopi dunia.

Sejalan dengan perkembangan zaman, aktivitas minum kopi kini sudah menjadi gaya hidup bagi anak - anak generasi millenial. Kondisi ini dapat dilihat dari tingginya angka pertumbuhan kafe atau kedai kopi di Jakarta. Tempat untuk menikmati kopi yang berkualitas tidak lagi menjadi dominasi dua merek terbesar dunia, seperti Starbucks atau di Coffee Bean. Melihat realitas yang terjadi pada fenomena kedai kopi sebagai gejala gaya hidup baru kaum muda, tentu saja banyak hal yang melatarbelakangi kaum muda memilih kedai kopi sebagai salah satu tempat menghabiskan waktunya tetapi yang perlu di perhatikan adalah seberapa jauh kedai kopi ini berpengaruh terhadap pola pikir dan tingkah laku kaum muda. Karena jumlah kedai kopi semakin meningkat, maka timbul peningkatan persaingan yang menjadi suatu tantangan dan ancaman bagi para pengusaha. Tantangan tersebut adalah bagaimana mendapatkan dan mempertahankan minat beli konsumen, serta ancamannya adalah jika konsumen mereka lebih memilih kedai kopi yang lain karna kurangnya promosi yang diberikan. Fenomena minat beli ini sesuai dengan data pengunjung Kedai Kopi Serasi yang setiap bulannya selalu mengalami peningkatan. Maka dari itu, peneliti juga ingin mengevaluasi keberhasilan minat beli yang berkaitan dengan hasil pra survei bauran promosi dan minat beli, yang sudah cukup baik. 
Terkait dengan minat beli pada konsumen kedai kopi serasi, menurut Kotler dan Armstrong (2012) perilaku pembelian konsumen dipengaruhi oleh beberapa faktor, yaitu: (1) Faktor Budaya, terdiri dari budaya, sub budaya dan kelas sosial; (2) Faktor Sosial: kelompok referensi, keluarga, peran dan status; (3) Faktor Pribadi, usia dan tahap daur hidup, pekerjaan, situasi ekonomi, gaya hidup, kepribadian dan konsep diri; dan (4) Faktor Psikologis: motivasi, persepsi, pembelajaran, kepercayaan dan sikap. Penelitian ini diharapkan dapat memberikan gambaran dan pemahaman yang lebih mendalam mengenai pengaruh Bauran Promosi dan Gaya Hidup terhadap Minat Beli pada suatu merek. Bagi pihak - pihak yang berkepentingan, diharapkan hasil penelitian ini dapat digunakan sebagai bahan pertimbangan, referensi atau pembanding guna membenahi aspek sejenis; (3) Bagi penelitian selanjutnya, dapat memberikan informasi dan data tambahan pengetahuan yang bermanfaat bagi para peneliti selanjutnya untuk penelitian yang akan dilakukan dengan topik sejenis.

\section{KAJIAN PUSTAKA}

Theory of planned behavior (TPB)

Teori perilaku terencana (TPB) merupakan teori utama dan telah banyak diakui memprediksi perilaku manusia dan dianggap teori psikologi sosial paling populer (Ajzen, 1991; Dean et al., 2012). TPB pertama kali dikembangkan sebagai perpanjangan dari teori Theory of reasoned action (TRA) yang menyatakan bahwa perilaku penggunaan produk berasal dari niat untuk menggunakan produk yang diturunkan dari sikap terhadap produk dan norma subyektif (Ajzen, I., \& Fishbein, M., dalam Sreen, Purbey, \& Sadarangani, 2018). TPB mengklaim bahwa kemungkinan melakukan perilaku tertentu meningkat jika seseorang memiliki sikap positif terhadap perilaku itu, persetujuan sosial untuk perilaku itu, serta lebih banyak kontrol untuk melakukan perilaku itu (Ajzen, 1991). Sebelumnya TPB telah diterapkan secara luas dalam banyak penelitian yang berkaitan dengan masalah niat perilaku pembelian dalam kajian pemasaran (Sreen et al., 2018; Martins et al., 2019; Silva et al., 2017).

Niat perilaku individu tergantung pada sikapnya terhadap perilaku dan norma subyektif yang terkait dengan perilaku tersebut. Di antara banyak pertanyaan berkaitan dengan perilaku konsumen, salah satu yang paling sulit untuk dijelaskan adalah mengapa konsumen melakukan pembelian tertentu, karena jawaban seperti itu sulit dijelaskan secara sederhana. Konsep niat beli mencerminkan perilaku konsumen yang dapat diperkirakan dalam keputusan pembelian jangka pendek di masa depan (Asshidin et al., 2016).

Bauran Promosi dan Minat beli

Promosi penjualan merupakan alat insentif, ditujukan untuk sasaran jangka pendek, dan digunakan untuk merangsang konsumen untuk mempercepat proses pembelian, atau untuk meningkatkan jumlah penjualan (Kotler dan Armstrong, 2012). Lebih lanjut dijelaskan bahwa bauran promosi digunakan untuk berkomunikasi dengan pelanggan tentang nilai merek dan untuk membangun hubungan antara toko dan pembelanja. Oleh karena itu, bauran promosi juga disebut bauran komunikasi pemasaran (Kotler dan Armstrong, 2012). Tujuan promosi adalah untuk membangun kesadaran, menciptakan minat, mengevaluasi informasi, menciptakan permintaan, membangun kesadaran dan loyalitas merek. Bauran promosi, yang disebutkan di atas, yang mencakup beberapa faktor eksternal, seperti suasana di dalam toko, interaksi dengan tenaga penjualan, dan keputusan pembelian pelanggan lainnya, dapat memengaruhi perjalanan pembelian di dalam toko. Namun, ada juga beberapa faktor internal yang dapat memengaruhi pembelian di dalam toko, seperti perilaku pembelian pribadi, kenikmatan proses tawar-menawar dan kenikmatan proses pembelian (Atsmon et al., 2010).

Sejalan dengan teori di atas, Yang dan Lee (2016) menemukan bahwa perilaku pembelian yang didorong oleh promosi di dalam toko adalah terkait dengan motivasi emosional pelanggan. 
Akhirnya, berbagai kegiatan promosi di dalam toko akan menimbulkan perasaan psikologis yang berbeda. Mahmoud et al. (2017) mengungkapkan bahwa ada efek signifikan dari elemen bauran pemasaran terhadap niat pembelian konsumen. Sementara pengetahuan lingkungan memoderasi hubungan antara bauran pemasaran dan niat beli.

$\mathrm{H}_{1}$ : bauran promosi berhubungan dengan niat pembelian

Gaya hidup dan Minat beli

Sejak diperkenalkan pada 1960-an, informasi gaya hidup konsumen telah menjadi instrumen populer dalam membuat keputusan manajemen iklan. Karakteristik gaya hidup memberikan informasi yang lebih akurat dan praktis tentang konsumen untuk digunakan pengiklan dalam memenuhi tuntutan pasar yang semakin kompetitif (Qing, Lobo, \& Chongguang, 2012). Kim, Park, Ki, \& Moon (2001) menemukan hubungan yang signifikan antara segmen gaya hidup pengguna internet, sikap mereka terhadap iklan internet dan niat pembelian produk. Berdasarkan temuan mereka, mereka menyimpulkan bahwa segmentasi gaya hidup sangat penting untuk memahami profil sosiopsikologis konsumen yang kompleks. Temuan mereka mengungkapkan efek moderat yang signifikan dari faktor gaya hidup pada hubungan antara sikap konsumen dan efektivitas iklan internet (Kim et al., 2001; Qing et al., 2012).

Studi terbaru yang dilakukan oleh Ahmad et al. (2019) menunjukkan hubungan yang signifikan antara gaya hidup dengan keterlibatan, kepribadian yang berani mengambil risiko, efikasi diri dan masalah privasi. Sedangkan, niat pembelian memiliki hubungan yang signifikan dengan self-efficacy internet dan gaya hidup. Sejalan dengan itu, Diyah dan Wijaya ((2017) memberikan kesimpulan bahwa gaya hidup konsumsi yang sehat adalah prediktor untuk niat beli produk. Penelitian yang dilakukan oleh Radivan Aulia (2018); Yulianti dan Deliana (2018) yang spesifik pada produk kopi juga berhasil membuktikan bahwa gaya hidup terkait dengan keputusan konsumen dalam membeli minuman Kopi.

$\mathrm{H}_{2}$ : gaya hidup berhubungan dengan niat pembelian

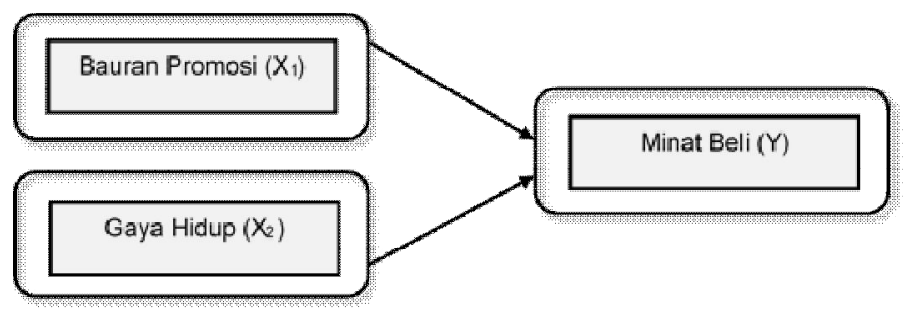

Gambar 1. Model konseptual

\section{METODE}

Desain penelitian

Penelitian ini merupakan penelitian yang bersifat kuantitatif, yaitu metode penelitian yang digunakan untuk meneliti pada populasi atau sampel tertentu, pengumpulan data menggunakan instrumen penelitian, analisis data bersifat kuantitatif / statistik, dengan tujuan untuk menguji hipotesis yang telah diterapkan. Dengan rumusan permasalahan kuantitatif asosiatif yaitu suatu rumusan masalah penelitian yang bersifat menanyakan hubungan antara dua variabel atau lebih. Variabel yang akan diuji dalam penelitian ini ialah bauran promosi dan gaya hidup sebagai variabel independen, minat beli sebagai variabel dependen. Peneliti menggunakan data kuantitatif dari hasil penyebaran kuesioner secara langsung kepada responden maupun melalui google form dengan memberikan sejumlah pertanyaan yang dapat diisi oleh responden. 
Prosedur Sampel

Populasi dalam penelitian ini ialah seluruh konsumen Kedai Kopi Serasi yang berdomisili di Cilincing, dengan jumlah sampel yang digunakan sebesar 130 sampel yang didapatkan dengan menggunakan metode penghitungan sampel hair et al dengan nilai $\alpha=5 \%$, dengan kriteria sampel adalah konsumen Kedai Kopi Serasi yang secara kebetulan bertemu dengan peneliti bila dipandang yang bersangkutan layak digunakan sebagai sampel. Teknik pengumpulan sampel yang digunakan dalam penelitian ini ialah probability sampling dengan teknik insedential sampling.

Pengukuran

Operasionalisasi variabel penelitian merupakan penjelasan dari masing - masing variabel yang digunakan dalam penelitian terhadap indikator - indikator yang membentuknya. Bauran Promosi merupakan sekumpulan alat pemasar untuk terlibat dan berkomunikasi dengan pelanggan dan pemangku kepentingan lainnya (Kotler dan Amstrong, 2015). Dengan dimensi advertising, personal selling, direct marketing. Gaya Hidup merupakan pola hidup seseorang di dunia yang diekspresikan dalam aktivitas, minat, dan opininya. Gaya hidup menggambarkan keseluruhan diri seseorang dalam berinteraksi dengan lingkungannya (Kotler dan Keller, 2012). Dengan dimensi activities dan interest. Minat Beli merupakan perilaku konsumen yang muncul sebagai respon terhadap objek yang menunjukkan keinginan seseorang untuk melakukan pembelian (Kotler dan Keller, 2009). Dengan dimensi minat transaksional, referensial, preferensial, eksploratif. Seluruh kuesioner di ukur dengan skala Likert 5 poin, yaitu $1=$ sangat tidak setuju -5 =sangat setuju.

Teknik analisis

Teknik analisis dalam penelitian ini menggunakan regresi linier berganda untuk memprediksi Y berdasarkan variasi nilai $\mathrm{X}$. variabel terikat $(\mathrm{Y})$ dalam penelitian ini minat beli, sedangkan variabel bebas $(\mathrm{X})$ adalah bauran promosi dan gaya hidu.

\section{HASIL DAN PEMBAHASAN}

Tahap pertama dalam analisis regresi adalah melakukan pengujian asumsi klasik. Setelah dinyatakan telah memenuhi asumsi klasik (multikolinieritas, normalitas dan heterokedastisitas) maka berikutnya adalah menginterpretasi hasil regresi yang ditampilkan pada tabel berikut:

Tabel 1. Hasil regresi

\begin{tabular}{llll}
\hline Variabel & Koefisien & t-value & Sig \\
\hline Bauran pemasaran & 0.190 & 6.038 & 0.000 \\
Gaya Hidup & 0.438 & 7.174 & 0.000 \\
\hline Adj. R Square & 0.608 & & \\
\hline
\end{tabular}

Berdasarkan tabel 1 maka persamaan regresi linier berganda dapat disimpulkan sebagai berikut: $\mathrm{Y}=3,551+0,190 \mathrm{X}_{1}+0,438 \mathrm{X}_{2}+\mathrm{e}$

Koefisien regresi variabel bauran promosi $\left(\mathrm{X}_{1}\right)$ sebesar 0.190 , artinya jika variabel independent lainnya bernilai tetap dan bauran promosi $\left(\mathrm{X}_{1}\right)$ mengalami kenaikan sebesar 1 satuan, maka minat beli (Y) akan mengalami kenaikan sebesar 0.190. Sehingga Kedai Kopi Serasi perlu memperhatikan strategi promosi mereka untuk memperbaiki serta meningkatkan minat beli pelanggan. Variabel bauran promosi $\left(\mathrm{X}_{1}\right)$ memiliki nilai thitung sebesar 6.038, sedangkan nilai ttabel sebesar 1.978 dan nilai P value (significant) pada tabel 4.17 menunjukkan nilai sebesar 0.000. Hal ini menunjukkan bahwa $6.038>1.978$ dan $0.000<0.05$. Artinya secara parsial variabel bauran promosi 
$\left(\mathrm{X}_{1}\right)$ berpengaruh secara signifikan terhadap variabel minat beli $(\mathrm{Y})$, sehingga $\mathrm{Ho}_{1}$ ditolak dan $\mathrm{Ha}_{1}$ diterima dan data mendukung hipotesis. Hasil ini sesuai dengan penelitian terdahulu yang telah dilakukan oleh Neneng Hayatul Madinah tahun 2017, dengan hasil penelitian yang telah dilakukan, terdapat pengaruh yang signifikan antara Bauran Promosi terhadap Minat Beli konsumen.

Koefisien regresi berganda Gaya Hidup $\left(\mathrm{X}_{2}\right)$ sebesar 0.438 , artinya jika variabel independent lainnya bernilai tetap dan Gaya Hidup $\left(\mathrm{X}_{2}\right)$ mengalamai kenaikan sebesar 1 satuan, maka minat beli (Y) akan mengalami kenaikan sebesar 0.438. Sehingga Kedai Kopi Serasi perlu mempertahankan serta meningkatkan faktor gaya hidup para konsumen pada Kedai Kopi Serasi. Variabel gaya hidup $\left(\mathrm{X}_{2}\right)$ memiliki nilai thitung sebesar 7.174, sedangkan nilai ttabel sebesar 1.978 dan nilai $\mathrm{P}$ value (significant) pada tabel 4.17 menunjukkan nilai sebesar 0.000. Hal ini menunjukkan bahwa 7.174 > 1.978 dan $0.000<0.05$. Artinya secara parsial variabel gaya hidup $\left(\mathrm{X}_{2}\right)$ berpengaruh secara signifikan terhadap variabel minat beli $(\mathrm{Y})$, sehingga $\mathrm{Ho}_{2}$ ditolak dan $\mathrm{Ha}_{2}$ diterima dan data mendukung hipotesis. Hasil ini sesuai dengan penelitian terdahulu yang telah dilakukan oleh Vina Auliya pada tahun 2017, dengan hasil penelitian yang telah dilakukan, terdapat pengaruh yang signifikan antara Gaya Hidup terhadap Minat Beli konsumen.

\section{Pembahasan}

Niat beli adalah proyeksi perilaku konsumen di masa depan yang akan secara signifikan berkontribusi pada konfigurasi sikap. Niat pembelian sering digunakan untuk memperkirakan penjualan produk dan layanan yang ada. Sementara, penelitian sebelumnya telah menunjukkan bahwa niat adalah salah satu dari prediksi penjualan. Selain itu, pengukuran niat beli telah menyebar luas dalam pemasaran modern (Asshidin et al., 2016).

Perusahaan riset pasar sering menggunakan niat beli untuk memperkirakan potensi penjualan produk baru. Selain itu, langkah-langkah niat pembelian telah sering digunakan untuk mengidentifikasi probabilitas pembelian produk dalam periode waktu yang ditetapkan. Niat pembelian telah diakui sebagai bagian dari perilaku konsumen. Oleh karena itu, perusahaan perlu mengidentifikasi apa yang membuat konsumen ingin membeli suatu produk. Perilaku pembelian konsumen dapat berubah dari waktu ke waktu karena faktor-faktor seperti gaya hidup sosial, industrialisasi negara dan pengaruh globalisasi yang mungkin mempengaruhi penilaian mereka terhadap produk. Perilaku pembelian adalah proses pengambilan keputusan dan tindakan orang yang terlibat dalam membeli dan menggunakan produk. Perilaku konsumen didefinisikan sebagai studi tentang unit pembelian dan proses pertukaran yang terlibat dalam memperoleh, mengkonsumsi, dan membuang barang, jasa, pengalaman dan ide. Perilaku konsumen dapat didefinisikan sebagai perilaku yang ditampilkan konsumen dalam mencari, membeli, menggunakan, mengevaluasi dan membuang produk dan layanan yang mereka harapkan akan memuaskan kebutuhan mereka (Asshidin et al., 2016).

Berdasarkan hasil analisis diperoleh kesimpulan bahwa variabel promosi bauran (X1) dan gaya hidup (X2) memiliki kepentingan yang positif terhadap minat beli (Y). Variabel positif berarti variabel kedua tergantung variabel dependen. Dengan koefisien regresi dari bauran promosi (X1) sebesar 0,190 dan gaya hidup sebesar 0,438 dan nilai konstanta sebesar 3,551. Dimana mempromosikan konsumen bauran promosi (X1) dan gaya hidup (X2) semakin baik, maka minat beli (Y) akan semakin tercipta. Penelitian ini sejalan temuan Yang dan Lee (2016) dan Mahmoud et al. (2017) mengungkapkan bahwa ada efek signifikan dari elemen bauran pemasaran terhadap niat pembelian konsumen. Sementara pengetahuan lingkungan memoderasi hubungan antara bauran pemasaran dan niat beli. Selain itu, gaya hidup telah dibuktikan memiliki efek positif dan signifikan terhadap minat beli, sehingga mendukung riset Ahmad et al. (2019); Diyah dan Wijaya ((2017); Aulia (2018); Yulianti dan Deliana (2018) berhasil membuktikan bahwa gaya hidup terkait dengan keputusan konsumen dalam membeli. 


\section{KESIMPULAN}

Penelitian ini mengungkapkan bahwa bauran promosi dan gaya hidup sama-sama memiliki dampak terhadap minat beli konsumen pada minuman kopi. Dengan demikian, komponen bauran promosi seperti advertising, personal selling, direct marketing, dan gaya hidup yang terdiri dari activities dan interest merupakan hal yang perlu diperhatikan pihak manajemen.

Keterbatasan

Penelitian ini dilakukan di kota Jakarta yang populasinya mewakili populasi perkotaan di seluruh Indonesia. Namun, lokasi survey dan minat beli konsumen yang diteliti spesifik pada minuman kopi maka penelitian mendatang perlu mengeksplorasi perilaku pembelian di kota-kota besar lainnya. Penelitian mendatang perlu juga memperluas model penelitian dengan memasukkan komponen nilai konsumen seperti simbolisme, kepedulian terhadap kesehatan, pemenuhan kebutuhan dasar dan hedonisme, gender, dan mempertimbangkan status sosial ekonomi dalam memprediksi niat beli konsumen, khususnya minuman kopi.

\section{REFERENSI}

Ahmad, W., Attiq, S., Ahmad, A., Ilyas, A., \& Kulsoom, K. (2019). Investigating the impact of Consumer's Involvement, Risk-taking Personality, Internet Self-Efficacy, Life Style and Privacy Concern on Online Purchase Intention and Shopping Adoption. Pakistan Business Review, 20(3), 582-599.

Atsmon, Y., Dixit, V., Magni, M. \& Maurice, L. S. (2010). China's new pragmatic consumers. McKinsey Quarterly, October, 1-13

Asshidin, N. H. N., Abidin, N., \& Borhan, H. B. (2016). Perceived quality and emotional value that influence consumer's purchase intention towards American and local products. Procedia Economics and Finance, 35, 639-643.

Diyah, I. A., \& Wijaya, T. (2017). Determinant Factors Of Purchase Intention On Green Product. Jurnal Aplikasi Manajemen, 15(1), 54-62.

Familmaleki, M., Aghighi, A., \& Hamidi, K. (2015). Analyzing the influence of sales promotion on customer purchasing behavior. International Journal of Economics \& Management Sciences, 4(4), 1-6.

Kotler PJ, Armstrong GM (2010) Principle of Marketing, Global Ed. New York: Pearson.

Lim, Y. J., Osman, A., Salahuddin, S. N., Romle, A. R., \& Abdullah, S. (2016). Factors influencing online shopping behavior: the mediating role of purchase intention. Procedia economics and finance, 35, 401-410.

Lorenz, B. A., Hartmann, M., \& Simons, J. (2015). Impacts from region-of-origin labeling on consumer product perception and purchasing intention-causal relationships in a TPB based model. Food quality and preference, 45, 149-157.

Mahmoud, T. O., Ibrahim, S. B., Ali, A. H., \& Bleady, A. (2017). The influence of green marketing mix on purchase intention: the mediation role of environmental knowledge. International Journal of Scientific \& Engineering Research, 8 (9), 1040-1048.

Martins, J., Costa, C., Oliveira, T., Gonçalves, R., \& Branco, F. (2019). How smartphone advertising influences consumers' purchase intention. Journal of Business Research, 94, 378-387.

Silva, A. G., Canavari, M., \& Wander, A. E. (2017). CONSUMERS INTENTION TOWARDS PURCHASING IP CERTIFIED BEANS: AN ANALYSIS USING THE THEORY OF PLANNED BEHAVIOUR (TPB). Organizações Rurais \& Agroindustriais, 19(3), 204-218.

Sreen, N., Purbey, S., \& Sadarangani, P. (2018). Impact of culture, behavior and gender on green purchase intention. Journal of Retailing and Consumer Services, 41, 177-189.

Kassim, N. M., \& Zain, M. M. (2016). Quality of lifestyle and luxury purchase inclinations from the perspectives of affluent Muslim consumers. Journal of Islamic Marketing, 7(1), 95-119.

Kapuge, K. D. L. R. (2016). Determinants of organic food buying behavior: special reference to organic food purchase intention of Sri Lankan customers. Procedia food science, 6, 303-308.

Kim, K. H., Park, J. Y., Ki, D. Y., \& Moon, H. I. (2001). Internet user lifestyle: its impact on effectiveness and attitude toward Internet advertising in Korea. Paper presented at the Annual Conference of the American Academy of Advertising, Salt Lake Cit 
Kotler, P., \& Garry, A. (2015). Marketing an Introduction. twelfth edition. USA: Pearson Education.

Kotler, P., \& Keller, K. L. (2012). Manajemen Pemasaran. Edisi 12. Jakarta: Erlangga.

Neuman, W. L. (2015). Metodologi Penelitian Sosial: Pendekatan Kualitatif dan Kuantitatif. Jakarta: PT. Indeks.

Qing, P., Lobo, A., \& Chongguang, L. (2012). The impact of lifestyle and ethnocentrism on consumers' purchase intentions of fresh fruit in China. Journal of Consumer Marketing, 29(1), 43-51.

Yang, D. J., \& Lee, C. W. (2016). In-store promotional mix and the effects on female consumer buying decisions in relation to cosmetic products. International Journal of Management, Economics and Social Sciences, 5(2), 35-56.

\section{PROFIL PENULIS}

Yosie Anne Putri adalah mahasiswa Manajemen, Fakultas Bisnis Institute Teknologi dan Bisnis Kalbis, Jakarta, Indonesia. Penulis memiliki ketertarikan penelitian di bidang pemasaran dan bisnis dan dapat dihubungi pada email: yosieputri15@gmail.com 